\title{
Refinery wastewater treatment via a multistage enhanced biochemical process
}

\author{
Chunhua Wang ${ }^{1 \bowtie}$, Zijian Chen ${ }^{2}$, Yuanhua Li ${ }^{1}$, Kejun Feng ${ }^{1}$, Zhongli Peng ${ }^{1}$, Yongjuan Zhu ${ }^{1}$ \& \\ Xiaofang Yang ${ }^{1}$
}

Petroleum refinery wastewater (PRWW) that contains recalcitrant components as the major portion of constituents is difficult to treat by conventional biological processes. An effective and economical biological treatment process was established to treat industrial PRWW with an influent COD of over $2500 \mathrm{mg} \mathrm{L}^{-1}$ in this research. This process is mainly composed of internal circulation biological aerated filter (ICBAF), hydrolysis acidfication (HA), two anaerobic-aerobic (A/O) units, a membrane biological reactor (MBR), and ozone-activated carbon $\left(\mathrm{O}_{3}-\mathrm{AC}\right)$ units. The results showed that, overall, this system removed over $94 \%$ of the $\mathrm{COD}, \mathrm{BOD}_{5}$, ammonia nitrogen $\left(\mathrm{NH}_{4}{ }^{+}-\mathrm{N}\right)$ and phosphorus in the influent, with the ICBAF unit accounting for $54.6 \%$ of COD removal and $83.6 \%$ of $\mathrm{BOD}_{5}$ removal, and the two $\mathrm{A} / \mathrm{O}$ units accounting for $33.3 \%$ of $C O D$ removal and $9.4 \%$ of $\mathrm{BOD}_{5}$ removal. The degradation processes of eight organic pollutants and their removal via treatment were also analyzed. Furthermore, 26 bacteria were identified in this system, with Proteobacteria and Acidobacteria being the most dominant. Ultimately, the treatment process exhibited good performance in degrading complex organic pollutants in the PRWW.

Petroleum refineries produce products such as gasoline, diesel, and lubricating oils that are integral to a nation's economic development. However, petroleum refinery wastewater (PRWW) contains many pollutants, including heavy metals, volatile phenols, and polycyclic aromatic hydrocarbons ${ }^{1}$, which are difficult to eliminate during regular wastewater treatment processes ${ }^{2}$. As such, researchers have developed a number of alternative wastewater treatment techniques aimed at removing these compounds, including biological techniques ${ }^{3}$, adsorptionbased techniques ${ }^{4}$, chemical-oxidation techniques ${ }^{5}$, and flotation- and oxidation-based techniques ${ }^{6}$. Biological techniques-for example, traditional anaerobic/aerobic (A/O) processes, membrane bioreactor (MBR) systems, or biological aerated filter (BAF) systems-are environmentally friendly, but they often lack the capacity to remove all pollutants in PRWW with an influent COD above $2000 \mathrm{mg} \mathrm{L}^{-17}$. Given this limitation, a number of combined treatment processes have been proposed in recent years ${ }^{8-11}$. Yang et al. ${ }^{8}$ combined microaerobic hydrolysis-acidification (MHA) and anoxic-oxic (A/O) units to treat petrochemical wastewater, achieving a COD removal efficiency of $75 \%$ and an ammonium removal rate of $94 \%$ at a hydraulic retention time (HRT) of $20 \mathrm{~h}$. Liu et al. ${ }^{9}$ combined an up-flow anaerobic sludge blanket (UASB) and immobilized biological aerated filters (IBAFs) to treat heavy oil wastewater containing dissolved recalcitrant organic compounds and low level of nitrogen and phosphorus. Their approach enabled the removal of $74 \%$ of $\mathrm{COD}, 94 \%$ of $\mathrm{NH}_{4}{ }^{+}-\mathrm{N}$, and $98 \%$ of suspended solids from the discharged wastewater. Finally, Wu et al. ${ }^{10}$ developed a sequence process that combined hydrolysis acidification (HA) and anoxic-oxic (A/O) units to treat petrochemical wastewater with a COD of $480 \mathrm{mg} \mathrm{L}^{-1}$. Their results showed that their developed approach was able to reduce the COD value to $60 \mathrm{mg} \mathrm{L}^{-1}$, in addition to reducing the presence of five other organic compounds (indene, 1,3-dioxolane, 2-pentanone, 2-chloromethyl-1,3-dioxolane and ethylbenzene). Despite their successes, each of these studies were constrained by certain limitations. For instance, the above techniques were tested at a lab scale using influent with a COD of $<1500 \mathrm{mg} \mathrm{L}^{-1}$, which is much lower than the COD typically found in industrial influent $\left(>2000 \mathrm{mg} \mathrm{L}^{-1}\right)^{12}$. Furthermore, despite combining 2 or 3 biological treatment units, the above approaches were unable to sufficiently treat refractory organic macromolecular pollutants in the influent. For example, Wu et al. ${ }^{10}$ still detected low acute toxicity in the effluents in their luminescent bacteria assay. Thus, there is still a pressing need for an effective and economical biological process that is capable of bringing heavily contaminated PRWW into compliance with discharge standards.

${ }^{1}$ School of Chemistry and Materials Engineering, Huizhou University, 3\# Building, Huizhou 516007, People's Republic of China. ${ }^{2} \mathrm{CNOOC}$ Huizhou Petrochemical Company, Huizhou 516018, People's Republic of China. ${ }^{\varpi}$ email: anglar@126.com 


\begin{tabular}{|l|l|l|l|l|l|l|l|}
\hline Items & COD & BOD $_{\mathbf{5}}$ & BOD $_{5}$ COD & TOC & C: : $\mathbf{P}$ & VFA & Sulfide \\
\hline S1 & $2554 \pm 538$ & $1198 \pm 302$ & 0.469 & $611 \pm 41$ & $257: 28: 1$ & $11.67 \pm 3.5$ & $8.24 \pm 5.9$ \\
\hline S2 & $1159 \pm 253$ & $196 \pm 58$ & 0.169 & $320 \pm 38$ & $68: 42: 1$ & $0.21 \pm 1.5$ & $1.87 \pm 1.5$ \\
\hline S3 & $1040 \pm 116$ & $114 \pm 11$ & 0.102 & $312 \pm 29$ & $38: 35: 1$ & $0.13 \pm 0.6$ & $5.23 \pm 3.3$ \\
\hline S4 & $230 \pm 28$ & $7 \pm 5$ & 0.03 & $84 \pm 24$ & $4: 25: 1$ & ND & $0.16 \pm 0.1$ \\
\hline S5 & $190 \pm 39$ & $2 \pm 0$ & 0.01 & $50 \pm 3$ & $1.5: 39: 1$ & ND & ND \\
\hline S6 & $110 \pm 19$ & ND & ND & $47 \pm 12$ & ND & ND & ND \\
\hline S7 & $50 \pm 2$ & ND & ND & $20 \pm 1$ & ND & ND & ND \\
\hline
\end{tabular}

Table 1. Analysis results of six indexes at each sampling point $\left(\mathrm{mg} \mathrm{L}^{-1}\right)$. S1-S7 sample point 1-7; ND no detection; $C O D$ chemical oxygen demand; $B O D_{5}$ Biochemical oxygen demand; TOC total organic carbons; VFA volatile fatty acids.

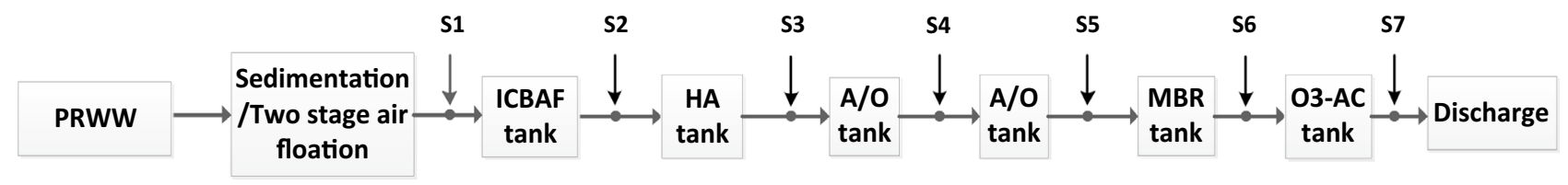

S1-S7: Sample point 1-7

Figure 1. Sampling points of the PRWW process. S1-S7: Sample point 1-7.

According to the refractory characteristics of PRWW, we examine a petrochemical wastewater treatment system consisting of an ICBAF tank, an HA tank, two sets of $\mathrm{A} / \mathrm{O}$ tanks, an MBR, and $\mathrm{O}_{3}-\mathrm{AC}$ units. Based on the traditional A/O process, the ICBAF tank and the HA tank were pre treated to improve the biodegradability of macro molecules and reduce the load of the A-O unit. The MBR unit and the $\mathrm{O}_{3}$-AC unit were installed to enhance the degradation of macro-molecular refractory organics, so that the sewage can meet the national discharge standard. Specifically, this research was aimed at achieving three key objectives: (1) to evaluate the system's performance with respect to the removal of organics, ammonia, nitrogen, and phosphorus; (2) to analyze the degradation process of the main organics in each tank; and (3) to identify the bacterial community of the sludge in each biological tank.

\section{Results and discussion}

Performance of the wastewater treatment process. The biological degradation performance in the $P R W W$. Table 1 shows the macro organic pollutant concentrations in wastewater samples collected at seven points throughout the PRWW treatment process (Fig. 1). The biological degradation performance is closely related to the $\mathrm{COD}$, the $\mathrm{BOD}_{5}$, the $\mathrm{BOD}_{5} / \mathrm{COD}$, and the $\mathrm{C}: \mathrm{N}$ : $\mathrm{P}$ values.

As shown in Table 1 , the $\mathrm{COD}, \mathrm{BOD}_{5}$, and the $\mathrm{BOD}_{5} / \mathrm{COD}$ values varied throughout the process, indicating that the wastewater had undergone different levels of biological degradation at the various sample collection points.

At the ICBAF influent (S1), the $\mathrm{BOD}_{5} / \mathrm{COD}$ value was 0.469 , and the $\mathrm{C}: \mathrm{N}: \mathrm{P}$ ratio was $257: 28: 1$. This nutrient ratio was conducive to the metabolism of pollutants by the microorganisms in the ICBAF unit, which resulted in a $54.6 \%$ in COD and an $83.6 \%$ decrease in $\mathrm{BOD}_{5}$ for hydraulic detention time (HRT) of $14 \mathrm{~h}$ in the ICBAF tank. This high removal efficiency indicated that the ICBAF tank played an important role in pretreating the PRWW. At the ICBAF effluent (S2), the $\mathrm{BOD}_{5} / \mathrm{COD}$ value was 0.169 and the C:N:P ratio was $68: 42: 1$, indicating a significant decrease in the wastewater's biodegradability compared to the influent (S1). To improve biodegradability, an HA tank was added. Unfortunately, the $\mathrm{BOD}_{5} / \mathrm{COD}$ of the resultant HA effluent (S3) further declined to 0.102 , which means that its biodegradability had also declined. This result is likely attributable to the large amount of oxygen in the effluent entering the HA tank from the ICBAF, as such oxygen levels would affect the anoxic environment in the HA tank. Thus, the efficiency of hydrolytic acidification is not fully realized under these conditions. The C:N:P ratio at the HA effluent (S3) was a reasonable 38:35:1. However, the carbon source quality was poor, which was not conducive to denitrification in the subsequent $\mathrm{A} / \mathrm{O}$ units. At the first A/O tank effluent (S4), the COD value decreased to about $30 \%$ of its value at the first A/O influent (S3) and the $\mathrm{BOD}_{5} / \mathrm{COD}$ value declined to 0.03 at HRT of $24 \mathrm{~h}$, indicating the COD at the first A/O tank effluent (S4) was mainly composed of refractory organics that are difficult to remove via the biochemical degradation process. In addition, the C:N:P ratio at the second A/O influent (S4) was 4: 25: 1, which indicates that the quantity and quality of the carbon source was insufficient for the subsequent biochemical treatment. At the second A/O unit (S5) - which was taken after glucose was added as an extra carbon source to improve biodegradability-the $\mathrm{BOD}_{5} / \mathrm{COD}$ value was 0.01 and the $\mathrm{C}: \mathrm{N}: \mathrm{P}$ ratio was $1.5: 39: 1$ at HRT of $28.8 \mathrm{~h}$. Notably, the $\mathrm{BOD}_{5} / \mathrm{COD}$ value could not be detected at the MBR effluent (S6), which indicates that the organics in the wastewater was almost entirely comprised of refractory organic pollutants. Similarly, the C:N:P ratio could also not be detected at the MBR effluent (S6). This result indicates lower levels of carbon and higher levels of nitrogen in S6, and thus, that the effluent is not suitable for biological treatment. To remove the refractory organics, the effluent was then sent 
to an $\mathrm{O}_{3}-\mathrm{AC}$ tank, where the $\mathrm{COD}$ and TOC concentrations further decreased significantly. Finally, neither the $\mathrm{BOD}_{5} / \mathrm{COD}$ value nor the C:N:P ratio were detected at the $\mathrm{O}_{3}-\mathrm{AC}$ effluent (S7); significantly, however, a COD value of $50 \pm 2 \mathrm{mg} \mathrm{L}^{-1}$ and a TOC value of $20 \pm 1 \mathrm{mg} \mathrm{L}^{-1}$ were obtained, which both satisfy the pollutant discharge standards for China's petrochemical industry.

The concentration of the VFA and sulfide in the PRWW. As shown in Table 1, the volatile fatty acid concentration (VFA) at the ICBAF influent (S1) was $11.67 \pm 3.5 \mathrm{mg} \mathrm{L}^{-1}$ and $0.21 \pm 1.5 \mathrm{mg} \mathrm{L}^{-1}$ at the ICBAF effluent (S2), which indicates that most of the VFAs were removed under aerobic conditions in the ICBAF tank. The VFA concentration further fell to $0.13 \pm 0.6 \mathrm{mg} \mathrm{L}^{-1}$ after treatment in the HA unit (S3), and was completely eliminated following treatment in the first A/O unit (S4). This result shows that the combined process examined in this research is effective for treating the industrial petroleum wastewater.

Table 1 also shows changes in the sulfide concentration between S1 and S7. The sulfide concentration at the ICBAF influent (S1) was $8.24 \pm 5.9 \mathrm{mg} \mathrm{L}^{-1}$, but it dropped to $1.87 \pm 1.5 \mathrm{mg} \mathrm{L}^{-1}$ after treatment in the ICBAF tank (S2). This dramatic decrease likely occurred due to the biodegradation and aeration stripping processes that occur in the ICBAF tank ${ }^{13}$. The sulfide concentration then increased to $5.23 \pm 3.3 \mathrm{mg} \mathrm{L}^{-1}$ in the HA tank (S3), due to the sulfate and oxides of sulfur being reduced to sulfide as a result of this tank's anaerobic nature at HRT of $25 \mathrm{~h}$. However, the sulfide was completely oxidized to sulfate after the subsequent two A/O units, which was evidenced by the absence of sulfide in the samples taken after the second A/O unit. Thus, this process successfully produced effluent that was safe to discharge.

Characterization of pollutants in the treatment process. Degradation of ammonia nitrogen. Biological nitrogen removal process consists of two steps: (1) oxidizing the $\mathrm{NH}_{4}{ }^{+}-\mathrm{N}$ into nitrate-nitrogen, nitritenitrogen, or some other nitrogen form, which is a critical step in the denitrification in PRWW ${ }^{14}$; and (2) denitrifying the nitrate or nitrite into nitrogen gas.

As shown in Table 2, $\mathrm{NH}_{4}{ }^{+}-\mathrm{N}$ removal was similar in the ICBAF and HA tanks, with results of $81.2 \pm 21 \mathrm{mg} \mathrm{L}^{-1}$ (ICBAF influent, S1), $89 \pm 15 \mathrm{mg} \mathrm{L}^{-1}$ (ICBAF effluent, S2), and $93 \pm 14 \mathrm{mg} \mathrm{L}^{-1}$ (HA effluent, S3) being obtained, respectively. These results were due to the ammoniation of microorganisms in the PRWW, which caused some degree of fluctuation in the TN and the $\mathrm{NH}_{4}{ }^{+}-\mathrm{N}$, as shown in Fig. 2. While the concentrations of $\mathrm{TN}$ and $\mathrm{NH}_{4}{ }^{+}-\mathrm{N}$ decreased significantly after the first A/O process (S4), the concentrations of nitrate $\left(\mathrm{NO}_{3}{ }^{-}\right)$ and nitrite $\left(\mathrm{NO}_{2}^{-}\right)$increased significantly. This variation in parameters between the first A/O influent (S3) and effluent (S4) indicated that significant ammoniation and nitrification had occurred in the process at HRT of $24 \mathrm{~h}$ and sludge retention time (SRT) of $45 \mathrm{~d}$. After the second A/O process (S5), the TN concentration decreased to $62.7 \pm 22 \mathrm{mg} \mathrm{L}^{-1}$, and the concentrations of $\mathrm{NH}_{4}{ }^{+}-\mathrm{N}, \mathrm{NO}_{3}{ }^{-} \mathrm{N}$ and $\mathrm{NO}_{2}{ }^{-} \mathrm{N}$ also declined significantly compared with the corresponding indexes in the first A/O effluent (S4). These results revealed that there was significant nitrification activity and poor ammonification and denitrification at HRT of $28.8 \mathrm{~h}$ and SRT of $45 \mathrm{~d}$ in the second A/O unit. Unfortunately, the nitrification and denitrification had no effect in the subsequent $\mathrm{MBR}$ and $\mathrm{O}_{3}$ - $\mathrm{AC}$ tanks. As such, the concentrations of TN and $\mathrm{NO}_{3}{ }^{-} \mathrm{N}$ in the effluent in the $\mathrm{O}_{3}-\mathrm{AC}$ tank were $22.4 \pm 3 \mathrm{mg} \mathrm{L}^{-1}$ and $6.1 \pm 1.3 \mathrm{mg} \mathrm{L}^{-1}$, respectively.

The removal of phosphorus. As shown in Table 2, the total phosphorus (TP) concentration decreased from $4.7 \pm 3.2 \mathrm{mg} \mathrm{L}^{-1}$ to $0.2 \pm 0.1 \mathrm{mg} \mathrm{L}^{-1}$ throughout the wastewater treatment process (i.e. between S1 and S7), which confirms that the phosphorus was utilized effectively by the microorganism in the biological treatment units. Biological dephosphorization consists of two steps: (1) Under anaerobic conditions, polyphosphate is hydrolyzed by englobing electron donors and absorbing the readily biodegradable COD to synthesize poly- $\beta$-hydroxy butyrate (PHB), which serves as the cell's energy storage material. (2) Under aerobic conditions, where the free oxygen functions as an electron acceptor, the phosphorus bacteria oxidizes the PHB to produce energy. The phosphorus bacteria uses the energy generated in these anaerobic and aerobic conditions to assimilate the phosphate from the wastewater in order to synthesize high-energy ATP and polyphosphate, which is then stored in cells ${ }^{15}$. The DO concentration was $3-4 \mathrm{mg} \mathrm{L}^{-1}$ in the ICBAF tank, aerobic-anoxic-anaerobic areas were formed in the biofilm from the surface to the inside of the filter. Since the aerobic phosphorus uptake is greater than the anaerobic phosphorus release, the TP concentration in the effluent at S2 was much lower than at S1. Moreover, Chemical precipitation also played an important role in the removal of phosphorus ${ }^{17}$. In the biofloccula and biofilm of each biochemical reaction unit, the $\mathrm{pH}$ value increased with denitrification, which promoted the formation of calcium hydroxyphosphate and struvite precipitation. These precipitates accumulated in sludge or biofilm. With back-washing (in ICBAF and MBR) and sludge discharge (in two A/O units), the phosphorus containing sediment was discharged from the wastewater treatment process. Under the synergistic effect of biological phosphorus removal and chemical precipitation, the TP concentration decreased once again as it passed through the two A/O units (S4, S5), the MBR tank (S6) and the $\mathrm{O}_{3}$-AC process (S7).

Characterization of organic pollutants in the process. Eight organic pollutants-namely, organic acids, esters, alcohols, heterocyclic compounds, alkanes, aromatic hydrocarbons, aldehydes and ketones, and phenols-were analyzed with respect to four attributes: (1)quantity, (2)carbon chain length range, (3)relative molecular weight distribution range, and (4)concentration. The samples were collected from the sedimentation/ two stage air floation effluent (S1) to the $\mathrm{O}_{3}$-AC effluent (S7), and the results are shown in Table 3.

The degradation of organic acids. Table 3 shows that the concentration and the quantity of organic acids decreased, while the molecular structure of organic acids became complex throughout the process. The most significant decrease in the concentration of organic acids occurred in the ICBAF tank and in the first A/O 
unit, which was due to the aerobic degradation of the volatile fatty acids (VFA) and small molecular organic acids (such as butyric acid, pentanoic acid, caproic acid, 3-methylvaleric acid, and heptanic acid). According to our prior work ${ }^{16}$, the aerobic degradation pathways include $\alpha$-oxidation, $\beta$-oxidation, combined oxidation of $\alpha$ and $\beta$, and aromatisation. Meanwhile, the concentration and the quantity of the organic acids basically remained unchanged after passing through the first A/O unit. Furthermore, there were no clear rules governing the changes to the molecular structures throughout the process, which indicates that the microorganisms had failed to degrade the complex organic acids. These complex organic acids were eliminated in the $\mathrm{O}_{3}$ - $\mathrm{AC}$ tank, where the concentration of organic acids was $3.29 \mathrm{mg} \mathrm{L}^{-1}$. This result confirms that the treatment process was able to nearly fully degrade the organic acids in the PRWW.

The degradation process of alcohols. As shown in Table 3, the indexes of alcohols varied throughout the process, with most being removed in the ICBAF tank and the first A/O unit. These two units offer oxygen-rich environments ${ }^{17}$ and long HRTs, which allows dehydrogenation to occur. The dehydrogenation of alcohols produces aldehydes, which lose two electrons and two hydrogen ions. As a result, the concentration of alcohols is decreased to levels that comply with the discharge standard.

The degradation process of esters. Table 3 shows the degradation of esters in different units. As can be seen, the concentration and quantity of esters gradually decreased throughout the process (S3 to S7). The exception to this trend occurred in the ICBAF tank (S2), where small molecules of acids (such as butyric acid, pentanoic acid, caproic acid, 3-methylvaleric acid, and heptanic acid, etc.) and alcohols (such as 3-penten-2-ol, 2-butoxyethanlo, etc.) formed and hydrolysed complex macromolecular esters (such as 2-methyl-2-amyl acrylate, ethyl 4-octenoate, etc.), causing an increase in both the concentration and the quantity of esters.

Nonetheless, the biochemical treatments applied in the subsequent units introduced enzymes that degraded or decomposed the esters into small molecular compounds via oxidation, reduction, and hydrolysis, among other processes. Among these treatments, enzymes produced by microorganisms played a particularly important role in severing the carboxylic acid ester bond, thereby generating small molecular carboxylic acid and alcohol ${ }^{18}$. Furthermore, metabolic processes, such as oxidation and conjugation, were used to transform the small molecular compounds into less toxic or non-toxic compounds.

The degradation process of heterocyclic compounds. Table 3 shows that the concentration of heterocyclic compounds gradually decreased throughout the treatment. However, the quantity of these compounds decreased after treatment in the ICBAF tank, but increased after treatment in the first A/O unit. The increase in the quantity and decrease in the concentration of these compounds in the first $\mathrm{A} / \mathrm{O}$ unit occurred as a result of the polycyclic heterocyclic compounds (such as 2-hydroxy-2,3-cyclododecane-nitroketone, methyl 2-(2,4-dinitrophenyl) sulfonyl benzoate, etc.) being cut off into smaller molecules, which were then biodegraded.

The mechanism that governs the biological degradation of heterocyclic compounds is an electrophilic reaction in which biodegradability increases with higher $\pi$ bond charge densities. There are three critical steps in the anaerobic degradation of heterocyclic compounds: (1) the partial scission of polycyclic and heterocyclic rings; (2) the cleavage of long chains; and (3) the degradation of these organics through anaerobic fermentation, which is enabled by specific enzymes contributed by microorganisms ${ }^{19}$. These fission products are then funneled into the tricarboxylic acid cycle through a variety of pathways, thus allowing the effluent in S7 to meet the discharge standard.

The degradation process of aldehydes and ketones. Table 3 shows that the aldehydes and ketones decomposed throughout the process, with concentrations decreasing from $65 \mathrm{mg} \mathrm{L}^{-1}$ at the ICBAF influent (S1) to $0.8 \mathrm{mg} \mathrm{L}^{-1}$ at the $\mathrm{O}_{3}$-AC effluent (S7). Notably, the concentration and quantity of aldehydes and ketones increased after treatment in the first A/O unit (S4), which was caused by the left over intermediate products of alcohol dehydrogenation. After leaving the first $\mathrm{A} / \mathrm{O}$ unit, the aldehydes were further oxidised to ketoacids ${ }^{17}$ via $\alpha$-oxidation or $\beta$-oxidation.

The degradation process of aromatic hydrocarbons. The concentrations of aromatic hydrocarbons at every sample point are shown in Table 3. First, the influent (in S1) was fed into the ICBAF tank; here, the aromatic hydrocarbons decreased in quantity, slightly increased in concentration, and significantly increased in molecular weight. These variations were due to the fact that it was difficult to decycle the oxidized hydrocarbons and multiple aromatic rings (such as 2-butyl-3-hexyl-1 h-indene, 1,2-diisobutylene benzene, etc.) in the effluent ${ }^{20}$. In addition, naphthalene, indene, and other polycyclic aromatic hydrocarbons were formed in the ICBAF by small aromatic compounds. After treatment in the HA tank (S3), the quantity and concentration of aromatic hydrocarbons in the PRWW decreased significantly. This decrease was attributable to the HA tank's anoxic ecosystem at HRT of $25 \mathrm{~h}$, which enabled the enzymes to convert the aromatic substrates into an ortho- or para-cyclohexane carboxylic acid derivatives, which was followed by the cleavage of the ring ${ }^{21}$. After the final treatment step in the $\mathrm{O}_{3}$ - $\mathrm{AC}$ tank, the concentration of aromatic hydrocarbons increased from $0.3 \mathrm{mg} \mathrm{L}^{-1}$ (the $\mathrm{O}_{3}$ - $\mathrm{AC}$ influent, S6) to $2.8 \mathrm{mg} \mathrm{L}^{-1}$ (the $\mathrm{O}_{3}$-AC effluent, S7). This increase was due to the aromatic hydrocarbons that remained in the effluent after the partial oxidization and decomposition of the benzene ring heterocyclic compounds. Thus, the quantity and the concentration of aromatic hydrocarbons increased in the effluent exiting the $\mathrm{O}_{3}$ - $\mathrm{AC}$ tank.

The degradation process of alkanes. The results for alkane removal are also listed in Table 3. As can be seen, the quantity of alkanes initially decreased in the ICBAF tank before increasing in the subsequent treatment 


\begin{tabular}{|l|l|l|l|l|l|}
\hline Items & TN & $\mathrm{NH}_{4}{ }^{+}-\mathbf{N}$ & $\mathrm{NO}_{3}{ }^{-} \mathbf{N}$ & $\mathrm{NO}_{2}{ }^{-} \mathbf{N}$ & TP \\
\hline S1 & $139.6 \pm 81$ & $81.2 \pm 21$ & $8.4 \pm 4$ & $\mathrm{ND}$ & $4.7 \pm 3.2$ \\
\hline S2 & $124.6 \pm 70.6$ & $89 \pm 15$ & $4.2 \pm 3.7$ & $\mathrm{ND}$ & $2.9 \pm 2.5$ \\
\hline S3 & $110.7 \pm 34.5$ & $93 \pm 14$ & $4.7 \pm 3.7$ & $\mathrm{ND}$ & $3 \pm 2.8$ \\
\hline S4 & $67.1 \pm 24.7$ & $28.3 \pm 15$ & $18.3 \pm 11$ & $4.6 \pm 2.6$ & $1.7 \pm 1.7$ \\
\hline S5 & $62.7 \pm 22$ & $1.1 \pm 0.4$ & $10.1 \pm 3$ & $0.03 \pm 0.03$ & $1.3 \pm 1.5$ \\
\hline S6 & $24.1 \pm 2.4$ & $0.5 \pm 0.1$ & $4 \pm 1.4$ & $\mathrm{ND}$ & $0.3 \pm 0.04$ \\
\hline S7 & $22.4 \pm 3$ & $\mathrm{ND}$ & $6.1 \pm 1.3$ & $\mathrm{ND}$ & $0.2 \pm 0.1$ \\
\hline
\end{tabular}

Table 2. Analysis results of macro organic pollutants at each sampling point ( $\left.\mathrm{mg} \mathrm{L}^{-1}\right)$. S1-S7 Sample point 1-7; $\mathrm{ND}$ no detection; $\mathrm{TN}$ total nitrogen; $\mathrm{NH}_{4}{ }^{+} \mathrm{N}$ ammonia nitrogen; $\mathrm{NO}_{3}-\mathrm{N}$ nitrate nitrogen; $\mathrm{NO}_{2}-\mathrm{N}$ nitrite nitrogen; TP total phosphorus.

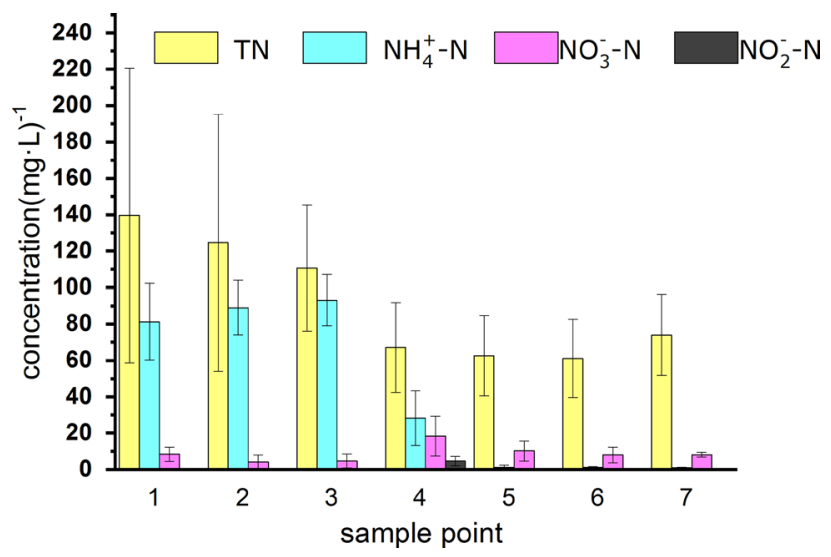

Figure 2. Variation of $\mathrm{TN}, \mathrm{NH}_{4}{ }^{+}-\mathrm{N}, \mathrm{NO}_{3}-\mathrm{N}$ and $\mathrm{NO}_{2}-\mathrm{N}$ at different sample point.

steps. This result was due to portions of the alkanes (such as 1-methylcyclohexane, 1-methyl-4-(1-methyl-ethyl) cyclohexane, etc.) being degraded in the ICBAF tank, and macro-molecular long-chain alkanes and cycloalkanes (such as 1,2,3,4,4a,5,6,8a-octahydronaphthalene, etc.) remaining in the wastewater. The concentration and quantity of alkanes increased in the HA tank, which was due to the insoluble macro-molecular alkanes being hydrolyzed into soluble alkanes by extracellular enzymes within the tank's anoxic environment at HRT of $25 \mathrm{~h}$. In the biochemical units (i.e. the two A/O units), the quantity of alkanes increased from 7 (at the HA effluent, S3) to 13 (at the second A/O effluent, S5), while the concentration decreased from $51 \mathrm{mg} \mathrm{L}^{-1}$ (at S3) to $11.2 \mathrm{mg} \mathrm{L}^{-1}$ (at S5). This result was due to the failure of the microorganisms to decompose the macro-molecular alkanes (i.e. 5-propyl-tridecane, 2,6,10,15-tetramethylheptadecane) when their molecular structures were quite stable. In addition, other pollutants, such as heterocyclic compounds and aromatic hydrocarbons, might decompose into small molecules made up of straight-chain alkanes and cycloalkanes at HRT of $24 \mathrm{~h}$ and $28.8 \mathrm{~h}$ in the two A/O units respectively. These small molecules were oxidized into organic acids in the addition-dehydrogenationhydroxylation process before being decomposed into $\mathrm{CO}_{2}$ and $\mathrm{H}_{2} \mathrm{O}^{17}$ in the two A/O units and the MBR tank (S6), where the alkane concentration declined to $10.8 \mathrm{mg} \mathrm{L}^{-1}$. Since the macro-molecular alkanes were oxidized into small molecular alkanes in the $\mathrm{O}_{3}$-AC tank, the concentration and quantity of alkanes increased, but the relative molecular weight decreased.

In summary, the pollutant concentrations were reduced by $99.5 \%$, with the best treatments results observed in the biochemical units. Indeed, the removal efficiency of organic acids, alcohols, aldehydes and ketones, aromatic hydrocarbons, and phenols in the biochemical units exceeded 97\%. The ICBAF tank displayed good ability to decompose small-molecule pollutants, the HA tank proved highly capable of decomposing most macro-molecular compounds into degradable small-molecule substances, and the two A/O units were efficient in transforming the micro-molecular organics into biodegraded compounds. Although non-biodegradable macro-molecular materials still remained in the effluent of the MBR tank, subsequent treatment in the $\mathrm{O}_{3}$-AC unit's ozone environment was able to decompose most of these remaining organics ${ }^{22}$. Therefore, the combined wastewater treatment process examined in this study is fully capable of treating industrial petroleum wastewater such that it complies with discharge standards.

The DHA value of the biochemical unit. Dehydrogenase enzyme activity (DHA) has been widely used to evaluate biological activity in soils, sediments, aerobic-activated sludge, and anaerobic sludge ${ }^{23}$ related to many of the different intracellular and specific dehydrogenase enzymes ${ }^{24}$ in the dehydrogenation process.

The DHA variations in the biochemical units are shown in Fig. 3. As can be seen, the highest DHA value was recorded for the ICBAF tank, at $15.12 \mathrm{mg}(\mathrm{L} \mathrm{h})^{-1}$, which indicates that the microorganisms within the 


\begin{tabular}{|c|c|c|c|c|c|c|c|c|c|c|}
\hline Sample point & Pollutant type & Organic acids & Esters & Alcohols & $\begin{array}{l}\text { Heterocyclic } \\
\text { compound }\end{array}$ & Alkanes & $\begin{array}{l}\text { Aromatic } \\
\text { hydrocarbons }\end{array}$ & $\begin{array}{l}\text { Aldehydes and } \\
\text { ketones }\end{array}$ & Phenols & Total \\
\hline \multirow{4}{*}{ S1 } & QP & 28 & 11 & 11 & 13 & 5 & 9 & 9 & 3 & 89 \\
\hline & \begin{tabular}{|l|} 
CCL \\
\end{tabular} & $\mathrm{C}_{2}-\mathrm{C}_{20}$ & $\mathrm{C}_{10}-\mathrm{C}_{20}$ & $\mathrm{C}_{5}-\mathrm{C}_{15}$ & $\mathrm{C}_{5}-\mathrm{C}_{11}$ & $\mathrm{C}_{8}-\mathrm{C}_{14}$ & $\mathrm{C}_{8}-\mathrm{C}_{11}$ & $\mathrm{C}_{6}-\mathrm{C}_{15}$ & $\mathrm{C}_{6}-\mathrm{C}_{10}$ & \\
\hline & MW & $60-312$ & $156-310$ & $86-224$ & 86-191 & $108-268$ & $106-142$ & $82-220$ & 94-154 & \\
\hline & C & 648 & 158 & 130 & 110 & 55 & 12 & 65 & 97 & \\
\hline \multirow{4}{*}{ S2 } & QP & 12 & 20 & 8 & 9 & 3 & 5 & 1 & 1 & 59 \\
\hline & CCL & $\mathrm{C}_{6}-\mathrm{C}_{20}$ & $\mathrm{C}_{9}-\mathrm{C}_{20}$ & $\mathrm{C}_{9}-\mathrm{C}_{17}$ & $\mathrm{C}_{6}-\mathrm{C}_{16}$ & $\mathrm{C}_{10}-\mathrm{C}_{12}$ & $\mathrm{C}_{14}-\mathrm{C}_{19}$ & $\mathrm{C}_{12}$ & $\mathrm{C}_{6}$ & \\
\hline & MW & $142-294$ & $156-334$ & $140-244$ & $113-244$ & $136-168$ & $186-256$ & 180 & 94 & \\
\hline & C & 90 & 228 & 90 & 98 & 38 & 18 & 7 & 0.7 & \\
\hline \multirow{4}{*}{ S3 } & QP & 13 & 18 & 8 & 9 & 7 & 2 & 1 & & 58 \\
\hline & CCL & $\mathrm{C}_{6}-\mathrm{C}_{20}$ & $\mathrm{C}_{9}-\mathrm{C}_{20}$ & $\mathrm{C}_{9}-\mathrm{C}_{17}$ & $\mathrm{C}_{6}-\mathrm{C}_{16}$ & $\mathrm{C}_{10}-\mathrm{C}_{15}$ & $\mathrm{C}_{14}-\mathrm{C}_{19}$ & $\mathrm{C}_{12}$ & & \\
\hline & MW & $142-294$ & $156-334$ & $140-244$ & $113-244$ & $136-168$ & $186-256$ & 180 & & \\
\hline & C & 84.3 & 177 & 82.6 & 97 & 51 & 11 & 6.7 & & \\
\hline \multirow{4}{*}{ S4 } & QP & 5 & 10 & 7 & 20 & 8 & 1 & 7 & & 58 \\
\hline & CCL & $\mathrm{C}_{14}-\mathrm{C}_{20}$ & $\mathrm{C}_{15}-\mathrm{C}_{26}$ & $\mathrm{C}_{10}-\mathrm{C}_{20}$ & $\mathrm{C}_{4}-\mathrm{C}_{22}$ & $\mathrm{C}_{10}-\mathrm{C}_{27}$ & $\mathrm{C}_{16}$ & $\mathrm{C}_{9}-\mathrm{C}_{21}$ & & \\
\hline & MW & $244-296$ & $240-372$ & $152-312$ & $102-385$ & \begin{tabular}{|l|}
$138-378$ \\
\end{tabular} & 210 & $152-358$ & & \\
\hline & C & 15.5 & 12.7 & 15 & 46.6 & 15 & 0.8 & 14 & & \\
\hline \multirow{4}{*}{ S5 } & QP & 5 & 12 & 7 & 15 & 13 & 1 & 4 & & 57 \\
\hline & CCL & $\mathrm{C}_{5}-\mathrm{C}_{18}$ & $\mathrm{C}_{16}-\mathrm{C}_{26}$ & $\mathrm{C}_{5}-\mathrm{C}_{20}$ & $\mathrm{C}_{4}-\mathrm{C}_{22}$ & $\mathrm{C}_{12}-\mathrm{C}_{21}$ & $\mathrm{C}_{16}$ & $\mathrm{C}_{10}-\mathrm{C}_{16}$ & & \\
\hline & MW & $116-284$ & $252-394$ & $86-310$ & $102-346$ & \begin{tabular}{|l|}
$170-296$ \\
\end{tabular} & 210 & $156-314$ & & \\
\hline & C & 17 & 15.6 & 4 & 37.4 & 11.2 & 1 & 2 & & \\
\hline \multirow{4}{*}{ S6 } & QP & 7 & 13 & 5 & 10 & 17 & 1 & 4 & & 57 \\
\hline & CCL & $\mathrm{C}_{8}-\mathrm{C}_{20}$ & $\mathrm{C}_{16}-\mathrm{C}_{30}$ & $\mathrm{C}_{5}-\mathrm{C}_{27}$ & $\mathrm{C}_{4}-\mathrm{C}_{22}$ & $\mathrm{C}_{11}-\mathrm{C}_{26}$ & $\mathrm{C}_{25}$ & $\mathrm{C}_{10}-\mathrm{C}_{21}$ & & \\
\hline & MW & $178-312$ & $266-438$ & $86-416$ & $102-346$ & 156-364 & 344 & 156-318 & & \\
\hline & C & 15 & 10.6 & 2.6 & 13.5 & 10.8 & 0.3 & 1.3 & & \\
\hline \multirow{4}{*}{ S7 } & QP & 3 & 7 & 8 & 6 & 27 & 5 & 2 & & 58 \\
\hline & CCL & $\mathrm{C}_{16}-\mathrm{C}_{22}$ & $\mathrm{C}_{16}-\mathrm{C}_{26}$ & $\mathrm{C}_{5}-\mathrm{C}_{20}$ & $\mathrm{C}_{4}-\mathrm{C}_{18}$ & $\mathrm{C}_{4}-\mathrm{C}_{28}$ & $\mathrm{C}_{11}-\mathrm{C}_{16}$ & $\mathrm{C}_{5}-\mathrm{C}_{7}$ & & \\
\hline & MW & $256-338$ & $268-394$ & $86-314$ & $102-281$ & 90-382 & $142-206$ & $84-148$ & & \\
\hline & C & 3.3 & 5 & 4.5 & 3.3 & 15.2 & 2.8 & 0.8 & & \\
\hline
\end{tabular}

Table 3. Organic pollutants in wastewater samples collected from different treatment units in a petroleum refinery wastewater plant. S1-7 sample point 1-7; QP quantity of pollutants; CCL carbon chain length range; $M W$ relative molecular weight distribution range; concentration $\left(\mathrm{mg} \mathrm{L}^{-1}\right)$.

tank were active enough to significantly reduce the COD and $\mathrm{BOD}_{5}$. The DHA value was $3.28 \mathrm{mg}(\mathrm{L} \mathrm{h})^{-1}$ in the HA tank, which indicates that the content of effective microorganisms was not large enough to hydrolyze organic compounds. The DHA values of the first A tank, the first O tank and the MBR tank were $4.4 \mathrm{mg}(\mathrm{L} \mathrm{h})^{-1}$, $4.72 \mathrm{mg}(\mathrm{L} \mathrm{h})^{-1}$, and $4.24 \mathrm{mg}(\mathrm{L} \mathrm{h})^{-1}$, respectively, which indicates good biodegradation of organic compounds. In contrast, the DHA values of the second A tank and the second O tank were $2.24 \mathrm{mg}(\mathrm{L} \mathrm{h})^{-1}$ and $3.16 \mathrm{mg}(\mathrm{L} \mathrm{h})^{-1}$, which indicates poor efficiency with respect to pollutant degradation. Thus, the removal mechanisms of the pollutants were clarified by verifying the DHA values in the different treatment units.

Bacterial community in the biochemical units. The PCR-DGGE technology based on 16S ribosomal DNA (rDNA) gene is a common molecular biology experiment to assess the microbial bacterial community. This technology was applied to investigate the bacterial community in different bioreactors. Because DGGE can only analyze DNA fragments with less than $500 \mathrm{bp}$, less information about phylogeny can be obtained. The 26 DGGE light bands in Fig. 4-I were excised, reamplified, sequenced, and reflected the dominant bacteria communities in the bioreactors, while Fig. 4-II denotes the different tanks in the process being using A to G. The horizontal lines in Fig. 4-II indicate the presence of a bacteria; thus, a higher density of lines indicates a higher level of bacteria in a treatment unit. Among the bioreactors, more bacteria were found in the ICBAF tank and the first $\mathrm{A} / \mathrm{O}$ unit than in the MBR tank, indicating that the bacterial communities in the early biological reaction treatment units were probably the result of their different bacterial growth environments and nutrient conditions.

Table 4 shows the phylum of the bacteria represented by the DGGE bands, including Proteobacteria, Acidobacteria, Firmicutes, and Methanosarcina. Figure 5 shows the relative abundance of the major bacterial community at phylum levels. As can be seen, Proteobacteria were dominant in all bioreactors, comprising a wide variety of aerobic, anaerobic, and facultative bacteria. The Proteobacteria associated with active methylotrophs by virtue of their physical and/or nutritional effects ${ }^{10}$ were able to degrade most organic contaminants and remove biological nitrogen and phosphorous ${ }^{8}$. These results correspond to Miura et al. research ${ }^{25}$, wherein Proteobacteria was considered the dominant phylum in the MBR unit and played an important role in the removal of organic matter. Acidobacteria were also widely distributed in all bioreactors, as shown in Fig. 5 Since the Acidobacteria are 


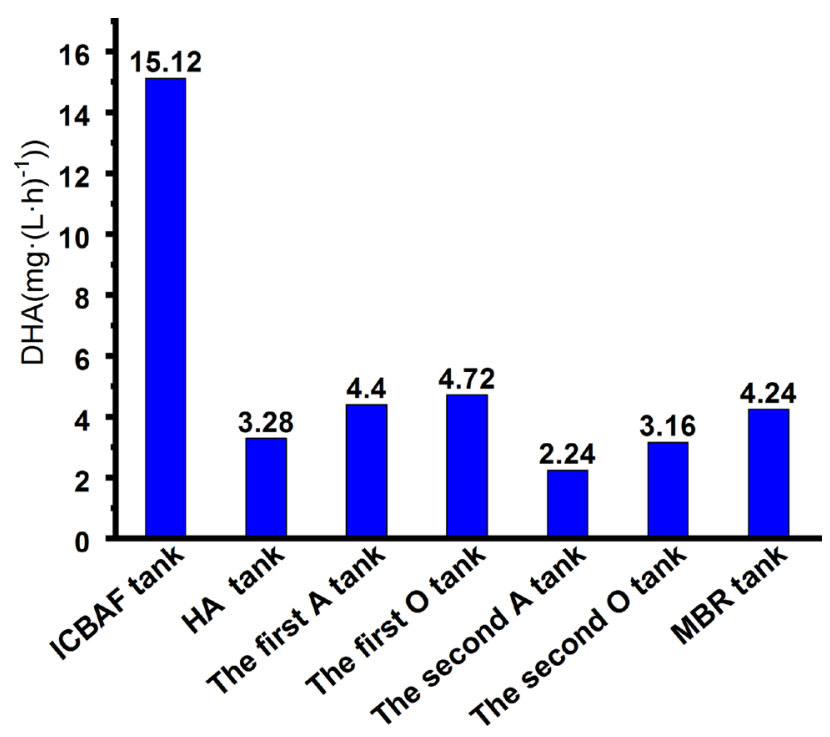

Figure 3. DHA of the biochemical units.

acidophilic $^{26}$, they are suitable for treating the high-acid, low-sulfur crude oil wastewater in this study. Firmicutes can produce extracellular enzymes such as cellulose, lipase, and protease, which are important for hydrolyzing and utilizing the refractory chemicals in petrochemical wastewater ${ }^{8}$. As shown in Fig. 5, most of the Firmicutes were found in the ICBAF tank, the HA tank, the first anaerobic tank, and the second aerobic tank, which was consistent with the decomposition of organic pollutants within these units. Bacteroidetes were found in the ICBAF tank, the HA tank, the first anaerobic tank, and the second aerobic tank. Bacteroidetes can break down macro-molecules such as protein, starch, cellulose, and fiber ${ }^{8}$ in the fermentation system, in addition to being able to degrade complex organic matter ${ }^{27}$. Methanosarcina, a hydrogenotrophic methanogen, was found in the ICBAF tank and the HA tank, which were where anaerobic respiration processes took place. The Methanosarcina were responsible for the production of $\mathrm{H}_{2}-\mathrm{CO}_{2}$, methanol, mono-, di-, and trimethylamines, acetate, and $\mathrm{CO}^{28}$. Nitrospirae were mainly found in the HA tank, the first anaerobic tank, and the first aerobic tank (Fig. 5.). Nitrospirae were effective in removing ammonia nitrogen ${ }^{29}$.

\section{Conclusions}

A petrochemical wastewater treatment system combining an ICBAF unit, an HA unit, two A/O units, an MBR unit, and an $\mathrm{O}_{3}$-AC unit was proposed for treating influent with COD values exceeding $2500 \mathrm{mg} \mathrm{L}^{-1}$. Nineteen indexes were analyzed at seven sample points throughout the treatment process, with the results confirming the proposed process' ability to eliminate nearly all pollutants. In addition, the bacterial community in these units was verified, with Proteosbacteria and Acidobacteria being identified as the dominant bacteria.

\section{Methods}

Wastewater and characteristics. The PRWW treatment plant examined in this study was designed to treat wastewater generated by oil production processes in Guangdong Province, South China, at a rate of 300 $\mathrm{m}^{3} \mathrm{~h}^{-1}$. The wastewater processed by this plant is produced via processes such as crude electric desalting, crude oil tank drainage, and alkylation, and contains a significant number of pollutants, including refractory organic matter, ammonia nitrogen $\left(\mathrm{NH}_{4}{ }^{+}-\mathrm{N}\right)$, and heavy metals.

A schematic of the wastewater treatment plant and sampling locations is shown in Fig. 1. First, the wastewater undergoes physical and chemical pretreatment, which entails hydraulic retention times (HRT) of $3.5 \mathrm{~h}$ in the inclined plate sedimentation tank, the cavitation air flotation tank, and the dissolved air flotation tank. Next, the wastewater is fed through the internal circulation biological aerated filter (ICBAF) reactor for further biological strengthening pretreatment. In the ICBAF, the DO concentration is maintained at $3-4 \mathrm{mg} \mathrm{L}^{-1}$, the volume load is maintained at $3.94 \mathrm{~kg}\left(\mathrm{M}^{3} \mathrm{D}\right)^{-1}$, and the HRT is $14 \mathrm{~h}$. After passing through the ICBAF, the wastewater flows into the hydrolysis acidification (HA) tank, where it stays for $25 \mathrm{~h}$. Following the HA, the wastewater is then fed into the activated sludge system, which consists of two anaerobic and aerobic (A/O) biological treatment processes, for $24 \mathrm{~h}$ and $28.8 \mathrm{~h}$, respectively. The sludge retention time in these two A/O units is 45 days. After A/O treatment, the wastewater undergoes membrane biological reactor (MBR) filtration, with an HRT of $3 \mathrm{~h}$ and and a DO concentration of between 3-4 $\mathrm{mg} \mathrm{L}^{-1}$. Finally, the wastewater is fed into the ozone-activated carbon $\left(\mathrm{O}_{3}-\mathrm{AC}\right)$ unit before being discharged.

Wastewater samples were collected after each major step in this process, as indicated by S1 to S7 in Fig. 1.

Analytical methods. The composition of organic pollutants in the influent and the concentrations of COD, $\mathrm{BOD}_{5}, \mathrm{NH}_{4}{ }^{+}-\mathrm{N}$, nitrate nitrogen $\left(\mathrm{NO}_{3}-\mathrm{N}\right)$, nitrite nitrogen $\left(\mathrm{NO}_{2}-\mathrm{N}\right)$, total nitrogen (TN), total phosphorus (TP), and volatile fatty acid (VFA) were analyzed by using the Standard Methods ${ }^{30}$. The total organic carbon (TOC) 


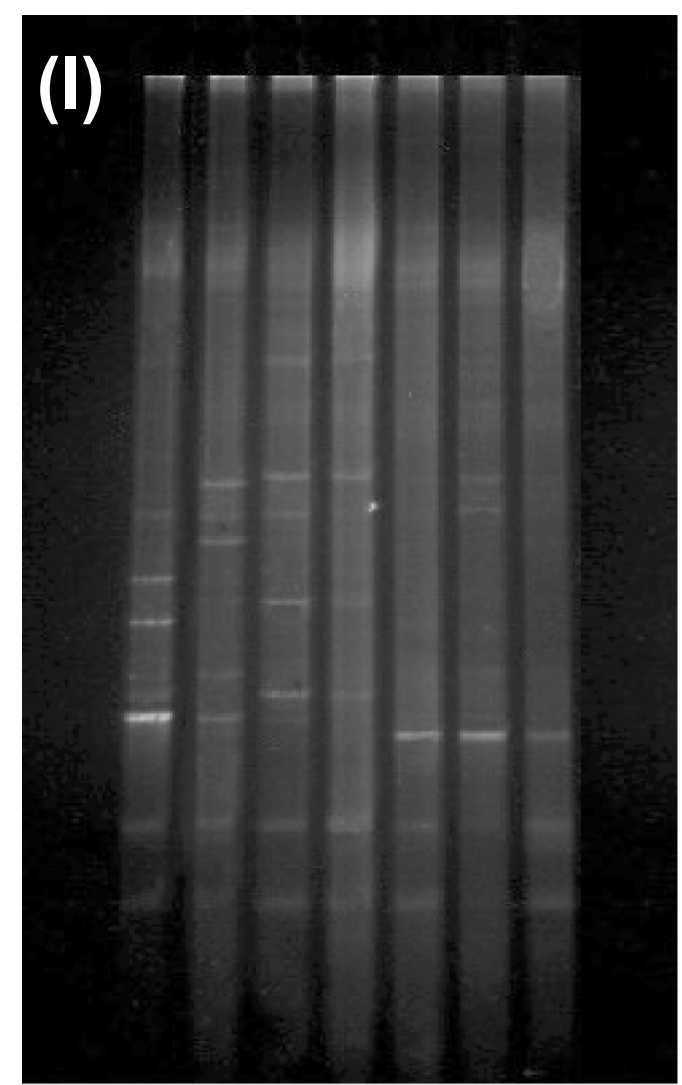

(II)

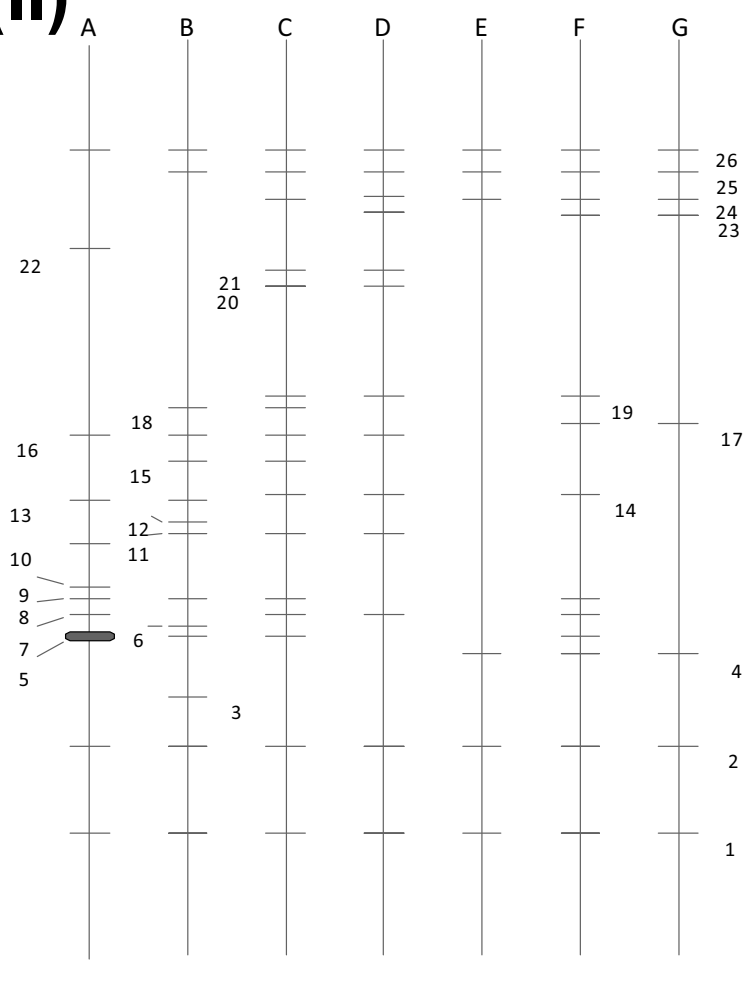

Figure 4. Comparison of microbial community of total bacteria in different samples (A: ICBAF; B: HA tank; C: the first A tank; D: the first O tank; E: the second A tank; F: the second O tank; G: MBR) Nos. 1-26 represent the light bands; the lines at the same height in II correspond to the band in I.

content in the wastewater samples was measured using a TOC analyzer (astro TOC UV/Turbo, Hach Co. USA), while the concentrations of petroleum and animal and vegetable oil were determined via the infrared photometric method. The concentration of volatile phenol was analyzed using the 4-aminoantipyrine extraction spectrophotometry method, and the sulfide content was assessed via methylene blue spectrophotometry. Finally, the composition of organic matter in the wastewater was measured using a GC/MS analyzer (Thermo Finnigan SSQ710).

Methods for the semi-quantification of organics in wastewater have been reported previously ${ }^{16}$. Prior to use, the SPE column (Supelco Company, United States; extraction packing: octadecyl C18; weight 5 g; effective volume $20 \mathrm{~mL}$ ) was pretreated by passing $10 \mathrm{~mL}$ of dichloromethane and $10 \mathrm{~mL}$ of ethyl acetate through it in order to remove impurities and allow the silica surface to be infiltrated more effectively. After pretreatment, the samples were loaded into the column, followed by dichloromethane to extract the organic compounds retained by the column. Finally, the extracts were evaporated and reconstituted to a volume of $1 \mathrm{~mL}$ using a $99.999 \%$ pure stream of nitrogen prior to analysis.

The stationary phase of the GC capillary column $(60 \mathrm{~m} \times 0.25 \mathrm{~mm} \times 0.25 \mu \mathrm{m})$ was a HP-5MS neutral silica gel capillary. Analyses were carried out in a split ratio of $1: 30$, with an inlet temperature of $29^{\circ} \mathrm{C}$, and helium as a carrier gas with a flow rate of $1 \mathrm{~mL} \mathrm{~min}^{-1}$. The temperature was maintained at $60^{\circ} \mathrm{C}$ for $10 \mathrm{~min}$, before being increased to $270{ }^{\circ} \mathrm{C}$ at increments of $10^{\circ} \mathrm{C} \mathrm{min}{ }^{-1}$, and then to $300{ }^{\circ} \mathrm{C}$ at increments of $20^{\circ} \mathrm{C} \mathrm{min}^{-1}$, where it was kept for $10 \mathrm{~min}$. The MS detector was operated in electron ionization $(70 \mathrm{eV})$ mode, with a scan range of 29-350 $\mathrm{m} \mathrm{z}^{-1}$. Finally, the MS ion source temperature was set to $200^{\circ} \mathrm{C}$.

Dehydrogenase enzyme activity (DHA) was measured using the modified triphenyl tetrazolium chloride (TTC) dehydrogenase activity test ${ }^{23}$. This test utilized a $20 \mathrm{~mL}$ experimental mixture made up of the following components: $10 \mathrm{~mL}$ wastewater sample; $1 \mathrm{~mL}$ reactivated activated sludge( $16 \mathrm{~g} / \mathrm{L}) ; 4 \mathrm{~mL} 0.4 \%$ Tris- $\mathrm{HCl}(\mathrm{pH} 8.4)$; $1 \mathrm{~mL}$ glucose $(0.1 \mathrm{~mol} / \mathrm{L}) ; 2 \mathrm{~mL}$ triphenyltetrazolium chloride (TTC) $(0.4 \%) ; 1 \mathrm{~mL} \mathrm{Na} \mathrm{SO}_{3}(0.36 \%)$ and $1 \mathrm{~mL}$ distilled water. The reactant was mixed thoroughly, and then left to sit for $120 \mathrm{~min}$ in an aqueous thermostat box at $37 \pm 1^{\circ} \mathrm{C}$ in the dark. After this period had elapsed, $1 \mathrm{~mL}$ of formaldehyde was added to the sample in order to stop the reaction. Finally, $5 \mathrm{~mL}$ acetone was added to the sample, which was followed by $10 \mathrm{~min}$ of shaking and $5 \mathrm{~min}$ of centrifugation at $4000 \mathrm{rpm}$. The absorbency of the supernatant was measured via a spectrophotometer at $485 \mathrm{~nm}$ and compared with a blank sample. The DHA was calculated according to the calibration curve for triphenyl formazan, with the average values being reported.

Polymerase chain reaction-denaturing gradient gel electrophoresis (PCR-DGGE) analysis was applied to analyze the microbial consortium in the ICBAF tank, the HA tank, the two A/O units, and the MBR tank, 


\begin{tabular}{|c|c|c|c|c|}
\hline Band & Organism & Phylum & Accession number & Blast similarity (\%) \\
\hline 1 & Gluconacetobacter sp. T61213-21-1a & Rhodospirillales & B778532.1 & 100 \\
\hline 2 & Thauera sp. BC0187 & Proteobacteria & KC166840.1 & 95 \\
\hline 3 & Soehngenia sp. B4119 & Methanosarcina & HQ133183.1 & 100 \\
\hline 4 & Geobacter sp. KS-54 & Proteobacteria & EU809806.1 & 91 \\
\hline 5 & Clostridiales bacterium De1161 & Firmicutes & HQ183782.1 & 100 \\
\hline 6 & Rhodocyclaceae bacterium MBfR_NS-150 & Proteobacteria & JN125706.1 & 98 \\
\hline 7 & Uncultured bacterium OX G09 & Proteobacteria & FN429550.1 & 100 \\
\hline 8 & Bacteroidales bacterium M6 & Bacteroidetes & KC769129.1 & 99 \\
\hline 9 & Firmicutes bacterium D004025G03 & Firmicutes & GU179831.1 & 100 \\
\hline 10 & Comamonadaceae bacterium B1-08 & Proteobacteria & JF754519.1 & 99 \\
\hline 11 & Clostridium sp.PACOL4_36 & Firmicutes & GQ257695.1 & 94 \\
\hline 12 & Uncultured bacterium ZBAF2-55 & Nitrospirae & HQ682030.1 & 100 \\
\hline 13 & Soehngenia sp. L35B_140 & Methanosarcina & JF946902.1 & 100 \\
\hline 14 & Acidobacteria bacterium SH2 & Acidobacteria & KC715858.1 & 100 \\
\hline 15 & Desulfomicrobium sp. & Proteobacteria & JX548546.1 & 100 \\
\hline 16 & Acidobacteria bacterium D199A & Acidobacteria & KC845239.1 & 100 \\
\hline 17 & Acidobacteria bacterium S2-047 & Acidobacteria & KF182983.1 & 99 \\
\hline 18 & Mesotoga sp. VNs100 & Thermotogae & KC800693.1 & 100 \\
\hline 19 & Pseudomonas sp. clone S2P1061 & Proteobacteria & KF145944.1 & 100 \\
\hline 20 & Acidobacteria bacterium SH6 & Acidobacteria & KC715862.1 & 95 \\
\hline 21 & Rhodospirillales bacterium WX36 & Proteobacteria & KC921187.1 & 98 \\
\hline 22 & Acidovorax sp. CPO 4.0017 & Proteobacteria & KC902440.1 & 98 \\
\hline 23 & Parvularcula sp.REV_R1PII_12F & Proteobacteria & FJ933486.1 & 100 \\
\hline 24 & Acidobacteria bacterium CNY_02641 & Acidobacteria & JQ402332.1 & 99 \\
\hline 25 & Verrucomicrobia bacterium & Verrucomicrobia & JF410432.1 & 99 \\
\hline 26 & Nitrosomonas nitrosa strain S12 & Proteobacteria & KF483596.1 & 98 \\
\hline
\end{tabular}

Table 4. Phylogenetic sequence affiliation of amplified $16 \mathrm{~S}$ rDNA sequence excised from DGGE of the biochemical units.

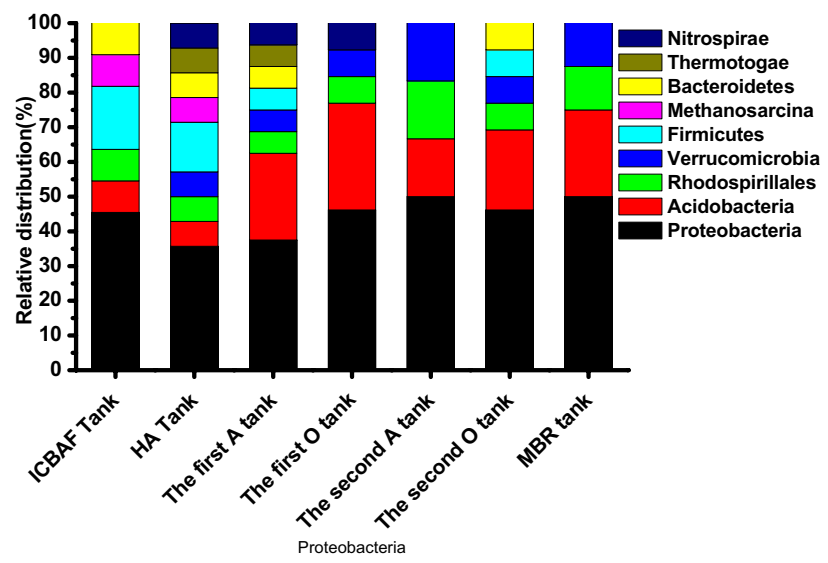

Figure 5. Relative abundance of the major bacterial community at phylum levels (only higher than $1 \%$ was present).

respectively. To this end, the procedure described by Xia et $\mathrm{al}^{31}$ was followed: (1) The DNA of the sludge samples was extracted using a Power Soil DNA Isolation Kit, and was examined using $1 \%$ agarose gel electrophoresis. (2) PCR amplification was performed using specifically synthesized primers, with the V3 and V4 regions of the 16S rDNA gene being selected for PCR. Specifically, the primers, 357F (5'-CCTACGGGAGGCAGCAG-3') and 518R (5'-ATTACCGCGGCTGCTGG-3'), were used. Replicate amplicons were pooled and visualized on $2.0 \%$ agarose gels using a Gel Doc XR system (Bio-Rad, US). (3) Amplicons of each sample were sent out for pyrosequencing by a commercial service (BGI, China), while the PCR products were sequenced by the Sangon Company (Shanghai, China). These sequences were then examined via BLAST (NCBI, USA) to identify and compare similarities. 


\section{Data availability}

The datasets used and analysed during the current study are available from the corresponding author on reasonable request.

Received: 24 November 2020; Accepted: 26 April 2021

Published online: 13 May 2021

\section{References}

1. Livingston, T. \& Abbassi, B. A comparative review and multi-criteria analysis of petroleum refinery wastewater treatment technologies. Environ. Res. 74, 66-78 (2018).

2. Pal, S., Banat, F., Almansoori, A. \& Abu Haija, M. Review of technologies for biotreatment of refinery wastewaters: Progress, challenges and future opportunities. Environ. Technol. Rev. 5, 12-38 (2016).

3. Wang, Y. et al. An alternative anaerobic treatment process for treatment of heavy oil refinery wastewater containing polar organics. Biochem. Eng. J. 105, 44-51 (2016).

4. Muftah, H. E., Manal, A. A. \& Sulaiman, A. Z. Evaluation of an activated carbon packed bed for the adsorption of phenols from petroleum refinery wastewater. Environ. Sci. Pollut. Res. 24, 7511-7520 (2017).

5. Abdelwahab, O., Amin, N. K. \& El-Ashtoukhy, E. S. Z. Electrochemical removal of phenol from oil refinery wastewater. J. Hazard. Mater. 163, 711-716 (2009).

6. Yang, H. G., Chun, H. Y. \& Pak, D. Improvement of sludge anaerobic degradability by combined electro-flotation and electrooxidation treatment. Biochem. Eng. J. 90, 44-48 (2014).

7. Muftah, H. E., Riham, S. \& Sulaiman, A. Z. Petroleum refinery wastewater treatment: A pilot scale study. J. Water Process Eng. 14, 71-76 (2016).

8. Yang, Q. et al. Treatment of petrochemical wastewater by microaerobic hydrolysis and anoxic/oxic processes and analysis of bacterial diversity. Bioresour. Technol. 196, 169-175 (2015).

9. Liu, G., Ye, Z., Tong, K. \& Zhang, Y. Biotreatment of heavy oil wastewater by combined upflow anaerobic sludge blanket and immobilized biological aerated filter in a pilot-scale test. Biochem. Eng. J. 72, 48-53 (2013).

10. Wu, C. et al. Appling hydrolysis acidification-anoxic-oxic process in the treatment of petrochemical wastewater: From bench scale reactor to full scale wastewater treatment plant. J. Hazard. Mater. 309, 185-191 (2016).

11. Verma, S., Prasas, B. \& Mishra, I. M. Pretreatment of petrochemical wastewater by coagulation and flocculation and the sludge characteristics. J. Hazard. Mater. 178, 1055-1064 (2010).

12. Varjani, S. J. Microbial degradation of petroleum hydrocarbons. Bioresour. Technol. 223, 277-286 (2017).

13. Cai, J., Zheng, P. \& Mahmood, Q. Effect of sulfide to nitrate ratios on the simultaneous anaerobic sulfide and nitrate removal. Bioresour. Technol. 99, 5520-5527 (2008).

14. Li, Y. et al. Effect of dissolved oxygen on simultaneous removal of ammonia, nitrate and phosphorus via biological aerated filter with sulfur and pyrite as composite fillers. Bioresour. Technol. 296, 122340 (2020).

15. Gao, L. et al. Nitrogen removal by the enhanced floating treatment wetlands from the secondary effluent. Bioresour. Technol. 234, 243-252 (2017).

16. Wang, C. H. et al. A study on the treatment efficiency of internal circulation biological aerated filters for refinery wastewater and the transformation of main organic pollutants. Environ. Sci. Pollut. Res. 27, 22902-22912 (2020).

17. Rittmann, B. E. \& McCarty, P. L. Environmnetal Biotechnology: Principles and Applications 350-472 (The McGraw-Hill Cpmpanies Inc, New York, 2004).

18. Saikia, N. et al. Biodegradation of beta cyfluthrin by Pseudomonas stutzeri strain S1. Biodegradation 16, 581-589 (2005).

19. Li, Y., Gu, G., Zhao, J. \& Yu, H. Anoxic degradation of nitrogenous heterocyclic compounds by acclimated activated sludge. Process. Biochem. 37, 81-86 (2001).

20. Cerniglia, C. E. Biodegradation of polycyclic aromatic hydrocarbons. Biodegradation 4, 351-368 (1992).

21. Evans, C. W. \& Fuchs, G. Anaerobic degradation of aromatic compounds. Ann. Rev. Microbiol. 42, 289-317 (1988).

22. Zhao, L., Ma, J. \& Sun, Z. Z. Oxidation products and pathway of ceramic honeycomb-catalyzed ozonation for the degradation of nitrobenzene in aqueous solution. Appl. Catal. B 79, 244-253 (2008).

23. Grenni, T. P., Caracciolo, A. B., Rodriguez-Cruz, M. S. \& Sanchez-Martin, M. J. Changes in the microbial activity in a soil amended with oak and pine residues and treated with linuron herbicide. Appl. Soil Ecol. 41, 2-7 (2009).

24. Zhang, X. et al. Biofilm characteristics in natural ventilation trickling filters (NVTFs) for municipal wastewater treatment: Comparison of three kinds of biofilm carriers. Biochem. Eng. J. 106, 87-96 (2016).

25. Miura, Y. et al. Bacterial community structures in MBRs treating municipal wastewater: Relationship between community stability and reactor performance. Water Res. 41, 627-637 (2007).

26. Barns, S. M., Cain, E. C., Sommerville, L. \& Kuske, C. R. Acidobacteria phylum sequences in uranium-contaminated subsurface sediments greatly expand the known diversity within the phylum. Appl. Environ. Microbiol. 73, 3113-3116 (2007).

27. Forss, J., Pinhassi, J., Lindh, M. \& Welander, U. Microbial diversity in a continuous system based on rice husks for biodegradation of the azo dyes Reactive Red 2 and Reactive Black 5. Bioresour. Technol. 130, 681-688 (2013).

28. Patil, S. S., Kumar, M. S. \& Ball, A. S. Microbial community dynamics in anaerobic bioreactors and algal tanks treating piggery wastewater. Appl. Microbiol. Biotechnol. 87, 353-363 (2010).

29. Juretschko, S., Loy, A., Lehner, A. \& Wagner, M. The microbial community composition of a nitrifying-denitrifying activated sludge from an industrial sewage treatment plant analyzed by the full-cycle rRNA approach. Syst. Appl. Microbiol. 25, 84-99 (2002).

30. S.E.P.A. Water and Wastewater Monitoring Methods 132-284. (Chinese Environmental Science Publishing House, 2002).

31. Xia, S., Guo, J. \& Wang, R. Performance of a pilot-scale submerged membrane bioreactor (MBR) in treating bathing wastewater. Bioresour. Technol. 99, 6834-6843 (2008).

\section{Author contributions}

Z.C. established and maintained the wastewater treatment process. Z.P. analyzed the macro pollutants in the wastewater. L.Y. analyzed the main organic compounds in wastewater by GC-MS. K.F. analyzed the degradation of ammonia nitrogen and phosphorus. Y.Z. analyzed the bacterial community in the biochemical units. X.Y. analyzed the DHA value of the biochemical units. C.W. performed the analysis of the degradation pathway of main organics, and was a major contributor in writing the manuscript. All authors read and approved the final manuscript. 


\section{Funding}

This work was supported by the Program for Innovative Research Team of Huizhou University, National Natural Science Foundation of China (No.21806191), the Special Fund for Guangdong Science and Technology Innovation Strategy of Huizhou (No.2019SC0301036).

\section{Competing interests}

The authors declare no competing interests.

\section{Additional information}

Correspondence and requests for materials should be addressed to C.W.

Reprints and permissions information is available at www.nature.com/reprints.

Publisher's note Springer Nature remains neutral with regard to jurisdictional claims in published maps and institutional affiliations.

(c) (i) Open Access This article is licensed under a Creative Commons Attribution 4.0 International License, which permits use, sharing, adaptation, distribution and reproduction in any medium or format, as long as you give appropriate credit to the original author(s) and the source, provide a link to the Creative Commons licence, and indicate if changes were made. The images or other third party material in this article are included in the article's Creative Commons licence, unless indicated otherwise in a credit line to the material. If material is not included in the article's Creative Commons licence and your intended use is not permitted by statutory regulation or exceeds the permitted use, you will need to obtain permission directly from the copyright holder. To view a copy of this licence, visit http://creativecommons.org/licenses/by/4.0/.

(C) The Author(s) 2021 